\title{
Recent progresses in marine microbial-derived antiviral natural products
}

\author{
Yun-Fei Teng ${ }^{1,2} \cdot$ Li Xu $^{1,2} \cdot$ Mei-Yan Wei ${ }^{1}$ Chang-Yun Wang ${ }^{1,2} \cdot$ Yu-Cheng Gu ${ }^{3} \cdot$ Chang-Lun Shao ${ }^{1,2}$
}

Received: 21 July 2020 / Accepted: 13 November 2020 / Published online: 21 November 2020

(C) The Pharmaceutical Society of Korea 2020

\begin{abstract}
Viruses have always been a class of pathogenic microorganisms that threaten the health and safety of human life worldwide. However, for a long time, the treatment of viral infections has been slow to develop, and only a few antiviral drugs have been using clinically. Compared with these from terrestrial environments, marine-derived microorganisms can produce active substances with more novel structures and unique functions. From 2015 to 2019, 89 antiviral compounds of 8 structural classes have been isolated from marine microorganisms, of which 35 exhibit antiH1N1 activity. This review surveys systematically marine microbial-derived natural products with antiviral activity and illustrates the impact of these compounds on antiviral drug discovery research.
\end{abstract}

Keywords Antiviral activity - Marine microorganism · Marine natural products $\cdot$ Structure-activity relationships

Yun-Fei Teng and Li Xu have contributed equally to this work.

Chang-Lun Shao

shaochanglun@163.com

1 Key Laboratory of Marine Drugs, The Ministry of Education of China, School of Medicine and Pharmacy, Ocean University of China, Qingdao 266003, People's Republic of China

2 Laboratory for Marine Drugs and Bioproducts, Qingdao National Laboratory for Marine Science and Technology, Qingdao 266200, People's Republic of China

3 Syngenta Jealott's Hill International Research Centre, Bracknell , Berkshire RG42 6EY, UK

\section{Introduction}

Since viral diseases (such as HIV, H1N1, HSV, etc.) have always been seriously threatening human life and health, antiviral compounds are continuously special attention. Some existing viral diseases including AIDS, hepatitis $\mathrm{B}$, influenza and other diseases that can cause millions of deaths every year have not been able to be eradicated completely. New viral diseases such as coronavirus are beginning to sweep the world, and related medical treatments are under investigation (Barlow et al. 2020; Li et al. 2020). Considering the importance of marine compounds in antiviral activity, the potency of some marine natural products to target SARS CoV-2 main protease (Mpro) (PDB ID 6MO3) was investigated (Khan et al. 2020) and reported the molecular docking analysis of 2019-nCoV inhibition by antiviral compounds from marine natural resources (Vijayaraj et al. 2020). Recent scientific studies triumphantly reported new antiviral agents, which generally inhibit the virus replication cycle through affecting the important host cell factor(s) for virus replication and/or viral elements (Lou et al. 2014). Despite the rapid development in antiviral pharmaceuticals over the past few decades, the emergence of recombinant viruses, drug resistance, and cell toxicity make it an urgent need to develop new antiviral agents with higher efficiency and lower toxicity (Moghadamtousi et al. 2015).

The oceans, with their unique aquatic environment and rich biodiversity, have proven to be a plentiful source of diverse natural products with significant antimicrobial, antiviral, antimalarial, antitumor, anti-inflammatory, and anti-oxidant activities (Hou et al. 2019). Since the exploration of marine microorganisms began in the 1960s, marine microorganisms have gradually become a new field of natural product research. Approximately 150 to 200 new compounds of alkaloids, sesquiterpenoids, polyketides, and 
others are obtained from marine fungi annually (Moghadamtousi et al. 2015). In recent years, with the popularity of genomic sequencing information and genome mining analysis, more and more drugs have been discovered from the marine environment, which will have a significant impact on the discovery of new natural products (Zhao 2011). With the continuous development of technologies for marine microbial research, synthetic biological approaches also provide a total of possible biological activities for the secondary metabolites of marine microbes (Seghal Kiran et al. 2018). All of these indicate that natural products derived from marine microorganisms will continue to play a pivotal role in drug discovery and development.

Marine microorganisms are known producers of antiviral agents and may provide unlimited biological resources for the production of therapeutic drugs for the treatment and control of viral diseases in humans, ever more novel compounds with potential as pharmaceuticals, which have strong potential market value (Bhadury et al. 2006). Currently, more than 200 natural products with promising levels of anti-HIV activity have been isolated from marine organisms, following bioassay-guided protocols (Yasuhara-Bell and $\mathrm{Lu}$ 2010). Halovirs A-E, isolated from the marine fungus Scytidium sp., exhibit potent antiviral activity against HSV-1 with $\mathrm{ED}_{50}$ values of 1.1, 3.5, 2.2, 2.0 and $3.1 \mu \mathrm{M}$, respectively (Rowley et al. 2003). Stachyflin, a novel terpenoid isolated from the fungus Stachybotrvs sp., shows significant antiviral activity against $\mathrm{H} 1 \mathrm{~N} 1$ with an $\mathrm{IC}_{50}$ value of $0.003 \mu \mathrm{M}$, which is much better than anti-H1N1 drugs amantadine and zanamivir (with $\mathrm{IC}_{50}$ values of 5.3 and $0.75 \mu \mathrm{M}$, respectively) (Minagawa et al. 2002a, b). This highlights the important role of marine natural products in the discovery of new antiviral agents.

In recent reviews on the same topic, some focused on specific compounds or compound categories (Goh et al. 2020), some were related to the biological activity of marine natural products (Deshmukh et al. 2017), some focused on biological or geographic regions (Pech-Puch et al. 2020), and others were more general. Since the marine antiviral natural products discovered recently have not been studied systematically in recent years, we summarize here the research progresses of these antiviral natural compounds from marine microorganisms published in the past five years and discuss the research status of marine microbial-derived antiviral compounds in this period including 89 compounds in 60 references. Compounds with effective antiviral activity will be described in detail.

\section{Marine microbial-derived antiviral compounds}

The following section describes antiviral compounds from marine microbial resources. The compounds are organized according to their chemical structural classes namely alkaloids, quinones, peptides, polyketones, pyrones, sterols, terpenoids, and others.

\section{Alkaloids}

Alkaloids are an important class of basic nitrogen-containing natural organic compounds that are abundant in animals and plants. In recent decades, tetramic acids have attracted researcher's attention, their chemical and biosynthetic methods have also been widely reported (Henning and Gelbin 1993; Schobert and Schlenk 2008). Even so, the natural products containing decalin ring that appear frequently in microorganisms also show different biological activities (Li et al. 2014). Recently, several tetramic acid derivatives containing a decalin ring with antiviral biological activity, trichobotrysins A (1), B (2) and D (3) (Sun et al. 2015), were obtained from a fermentation broth of the fungal strain Trichobotrys effuse derived from the deep-sea sediment collected from the South China Sea. These compounds were shown to have activity against $\mathrm{HSV}-1$ with $\mathrm{IC}_{50}$ values of $3.08,9.37$ and $3.12 \mu \mathrm{M}$, respectively.

Neosartoryadins A (4) and B (5) (Yu et al. 2015), were isolated from the endophytic fungus Neosartorya udagawae. They have a common unique pyrido [2,1-b]-quinazoline framework and a tetrahydrofuran ring, and the quinazoline is conjugated with a pyridine ring. Such compounds were first isolated from Aspergillus fumigates in 1992 (Numata et al. 1992). Using the cytopathic effect (CPE) inhibition assay to evaluate their antiviral activity, both $\mathbf{4}$ and $\mathbf{5}$ exhibited antiviral activity against $\mathrm{H} 1 \mathrm{~N} 1$ with $\mathrm{IC}_{50}$ values of 66 and $58 \mu \mathrm{M}$, respectively (ribavirin as positive control, $\left.\mathrm{IC}_{50}=94 \mu \mathrm{M}\right)$. Biosynthetically, these compounds may derive from an assembly by L-tryptophan, ATA, L-valine, and 2-aminoisobutyric acid (Aib).

Pyrazine heterocycle is an important pharmacophore present as a basic scaffold in various clinical drugs with a wide range of pharmacological and therapeutic activities, such as antitumor, anti-inflammatory, antithrombotic, anti-diabetic, and anti-tubercular (Dolezal and Zitko 2012; Miniyar et al. 2013). Trypilepyrazinol (6) (Li et al. 2019b) isolated from marine-derived fungus Penicillium sp. is characterized by a pyrazine motif and has a broad spectrum of antiviral activity against human immunodeficiency virus (HIV) and hepatitis $\mathrm{C}$ virus (HCV) with $\mathrm{IC}_{50}$ values of 4.6 and $7.7 \mu \mathrm{M}$, respectively.

Raistrickindole A (7) and raistrickin (8) (Li et al. 2019a) were isolated from the marine-derived fungus Penicillium raistrickii. Both $\mathbf{7}$ and $\mathbf{8}$ showed anti-HCV activity in vitro with $\mathrm{EC}_{50}$ values of 5.7 and $7.0 \mu \mathrm{M}$, respectively (as compared to $0.05 \mu \mathrm{M}$ of the positive control VX-950). Compound 7 had an unusual pyrazino[ $\left[1^{\prime}, 2^{\prime}: 2,3\right]-[1,2]$ oxazino $[6,5-b]$ indole tetraheterocyclic ring system, and this 
novel structure provides more possibilities for the discovery of antiviral compounds.

9(10H)-Acridanone (9) (Manimaran et al. 2018) (Fig. 1) was extracted from Streptomyces fradiae strain VITMK2, isolated from marine soil sediment sample collected from the mangrove forest region of Pichavaram, Tamil Nadu, India. The shrimp infected with WSSV and treated with $9(500 \mu \mathrm{g}, 250 \mu \mathrm{g}$, and $125 \mu \mathrm{g})$ showed survival rates of $88.89 \%, 83.33 \%$ and $55.56 \%$, respectively. Docking of the compound with VP26 and VP28 of WSSV drug target proteins showed the least binding energy of $-5.71 \mathrm{kcal} / \mathrm{mol}$ and $-5.21 \mathrm{kcal} / \mathrm{mol}$, respectively, predicting the strong interaction of the compound with VP26 and VP28.

\section{Quinones}

Quinones are a class of aromatic organic compounds with two double bonds and a six-carbon atom cyclic diketone structure. They are often found in nature as pigments in animals, plants, and microorganisms. Two anthraquinones, aspergilols H (10) and I (11) (Huang et al. 2017), were isolated from fungus Aspergillus versicolor derived from the deep-sea sediment sample collected from the South China Sea. In vitro antiviral assay indicated that these compounds showed significant anti-HSV-1 activity with $\mathrm{EC}_{50}$ values of 4.68, $6.25 \mu \mathrm{M}$ and CC50 values of 108.6, $50.7 \mu \mathrm{M}$, respectively (The corresponding EC50 and CC50 values of positive control acyclovir were 3.0 and $>1000 \mu \mathrm{M}$, respectively).

A citrinin dimer, seco-penicitrinol A (12) (Yang et al. 2018) was isolated from the extracts of the coculture of two marine algal-derived endophytic fungal strains Aspergillus sydowii and Penicillium citrinum. Compound $\mathbf{1 2}$ showed inhibitory activity towards influenza neuraminidase in vitro with an $\mathrm{IC}_{50}$ value of $24.7 \mu \mathrm{M}$ (oseltamivir as positive control, $\mathrm{IC}_{50}=3.6 \mu \mathrm{M}$ ).

Two anthraquinone derivatives, (-)-2' $R$-1-hydroxyisorhodoptilometrin (13) and methyl 6,8-dihydroxy-3-methyl9-oxo-9H-xanthene-1-carboxylate (14) (Jin et al. 2017) (Fig. 2) were isolated from the acidic fermentation broth ( $\mathrm{pH}$ 2.5) of Penicillium sp. OUCMDZ-4736 collected from the sediment around roots of mangrove (Acanthus ilicifolius). Low $\mathrm{pH}$ induced the fungus producing abundant and diverse secondary metabolites. Compared with the positive control lamivudine, $\mathbf{1 3}$ showed stronger anti-hepatitis B virus activity by inhibiting $\mathrm{HBsAg}$ and $\mathrm{HBeAg}$ secretion in HepG2.2.15 cells.

Actinomycetes isolated from mangrove ecosystem plays an important role in protecting human health by having the
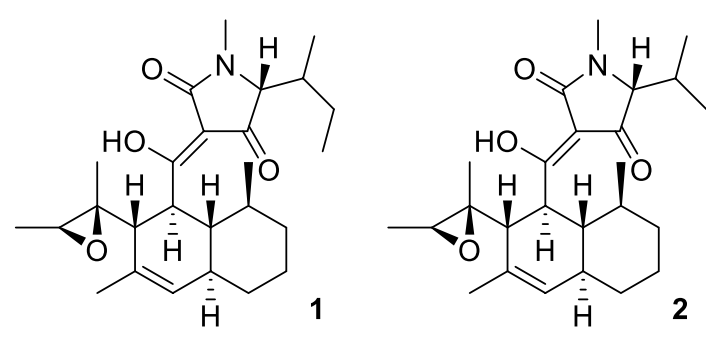<smiles>CN1c2ccccc2C1CCCn1c(C=O)nc2ccccc2c1=O</smiles>

Fig. 1 Chemical structures of 1-9<smiles>[10BH2]</smiles>

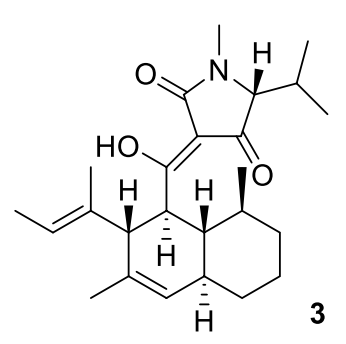

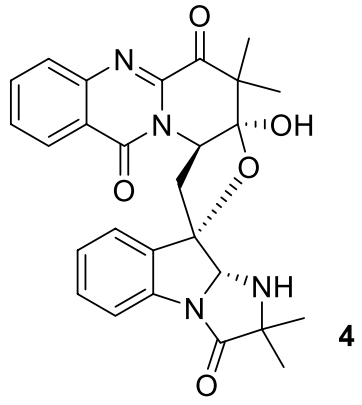<smiles>CC[C@H](C)c1nc(OC)c(Cc2c[nH]c3ccccc23)nc1O</smiles><smiles>O=C1Cn2c(nc3ccccc3c2=O)-c2ccccc2N1</smiles>

6<smiles>C/C=C\C(O)Oc1cccc2c1C(=O)c1ccccc1C2=O</smiles> 
<smiles>COC(=O)c1cc(O)c(O)c2oc3cc(O)cc(O)c3c(=O)c12</smiles><smiles>Cc1c(O)cc2oc3c4c(c(C)c(O)c3c(=O)c2c1[C@H](C)[C@@H](C)O)[C@@H](C)[C@H](C)O4</smiles>

12<smiles>O=c1c2ccccc2[nH]c2ccccc12</smiles>

Fig. 2 Chemical structures of 11-15

antagonistic activity against disease causing microorganisms. A novel bioactive compound, (Z)-1-((1-hydroxypenta2,4-dien-1-yl)oxy)anthracene-9,10-dione (15) (Avilala et al. 2018) extracted from Nocardia alba KC710971 showed antiviral activity against two poultry viruses NDV and IBDV.

\section{Peptides}

Peptides are short chains of between 2 and 50 amino acids, linked by peptide bonds. Chains of less than 10 or 15 amino acids are called oligopeptides, and include dipeptides, tripeptides, and tetrapeptides. A class of thiodiketopiperazine-type alkaloids, eutypellazines A-L (16-27) (Niu et al. 2017) (Fig. 3), were extracted from deep-sea derived fungus Eutypella sp. collected from the South Atlantic Ocean. In vitro antiviral experiments showed that these compounds have antiviral activities and low cytotoxicity $\left(\mathrm{CC}_{50}>100 \mu \mathrm{M}\right)$. Compound 20 showed the strongest inhibitory effect on HIV-1 with an $\mathrm{IC}_{50}$ value of $3.2 \pm 0.4 \mu \mathrm{M}$ and the rest (16-19 and 21-27) demonstrated $\mathrm{IC}_{50}$ values of anti-HIV activity $14.8 \pm 1.2,11.5 \pm 0.8,10.7 \pm 1.3,8.5 \pm 0.5$, $16.6 \pm 0.5,18.2 \pm 1.3,13.3 \pm 0.6,6.7 \pm 2.1,4.9 \pm 1.1$, $5.8 \pm 0.7$, and $5.9 \pm 0.9 \mu \mathrm{M}$, respectively. Structure-activity relationships (SAR) indicated that these analogues with thiomethyl group at C-2/C-2' (19 and 20) showed more active than those with sulfide bridge (16-18 and 21-23) in the pentacyclic thiodiketopiperazines. A comparison of the inhibitory effect between $\mathbf{1 9}$ and $\mathbf{2 0}$ revealed a double bond at $\mathrm{C}-6^{\prime} / \mathrm{C}-7^{\prime}$ in $\mathbf{2 0}$ enhancing the activity. In regard to 24-27, the analogues with thiomethyl group at C-2/C-2' (25) showed stronger effect than those with hydroxyl substitution (25-26), whereas the analogue with methoxy/hydroxyl substitution at C-2/C-2' dramatically reduced the activity.
Another study indicated that $\mathbf{2 5}$ showed the reactivation on latent HIV-1 transcription with a dose-dependent manner, whereas the remaining compounds exerted inactive in a dose of $100 \mu \mathrm{M}$. Compound $\mathbf{2 5}$ had the reactivation activity at $80 \mu \mathrm{M}$, which is comparable to the positive control of prostratin $(5 \mu \mathrm{M})$ and SAHA $(2.5 \mu \mathrm{M})$.

Rubrumlines A-O (28-42) (Chen et al. 2015) (Fig. 4) is a class of prenylated indole diketopiperazines isolated from marine-derived fungus Eurotium rubrum. Antiviral tests showed that they all have weak anti-influenza A/WSN/33 virus activity. Structure-activity relationships (SAR) indicated that 28-42 exhibited a variety of antiviral activities dependent on the substituent groups and the olefinic location at diketopiperazine unit. The analogues with a saturated $\mathrm{C}_{8}-\mathrm{C}_{9}$ bond (33-34, 37 and 40-42) exerted weak antiviral effects. For the analogues with a $\Delta^{8,9}$ bond, $\mathbf{3 1}$ with a $\Delta^{12,15}$ unit at the diketopiperazine moiety instead of alanine unit such as $\mathbf{2 8 - 3 0 , 3 5}$ and $\mathbf{3 6}$ significantly enhanced the antiviral activity. The analogues with a hydroxy group at C-15 of alanine unit (37-38) and with a ketone at C-12 (39) exhibited weak antiviral effects. Rubrumline $\mathrm{N}(\mathbf{4 1})$ with a $\mathrm{MeO}$ group at C-8 increased antiviral effect in comparison with rubrumline $\mathrm{M}$ (40) in which an $\mathrm{OH}$ group was substituted at $\mathrm{C}-8$. The analogues with an isoprenyl unit in indole ring displayed stronger cytotoxic effects than those linked by an oxygenated isoprenyl unit (28-29 and 35-36) at a dose of $100 \mu \mathrm{M}$.

A pair of enantiomeric alkaloid dimers, $(+)$-and (-)-pestaloxazine A (43 and 44) (Jia et al. 2015b) (Fig. 5), with an unprecedented symmetric spiro-[oxazinane-piperazinedione] skeleton consisting of 22 carbons and 12 heteroatoms, were isolated from a fungus Pestalotiopsis sp., derived from a soft coral. Pestaloxazine A belongs to the 


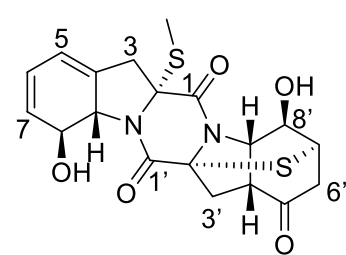

16

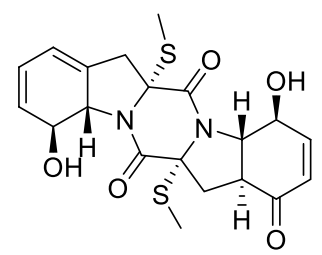

20<smiles>CSC1(Cc2ccccc2O)NC(=O)/C(=C\c2ccccc2)NC1=O</smiles>

24

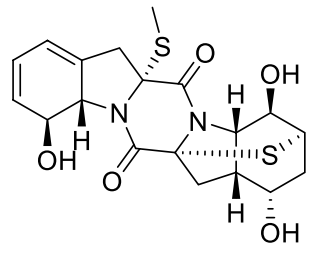

17

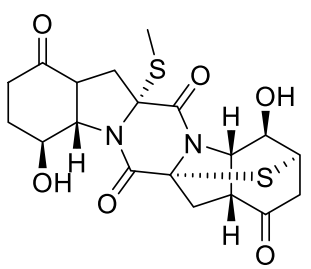

21<smiles>CSC[C@]1(Cc2ccccc2)NC(=O)[C@](CSC)(SC)NC1=O</smiles>

25

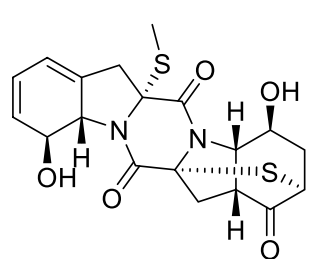

18<smiles>CS[C@]12CC3=CC=C[C@H](O)[C@]3(C)N1C(=O)[C@]1(SC)C[C@H]3C(=O)CC[C@@H](O)[C@H]3N1C2=O</smiles>

19

22<smiles>CS[C@@]1(Cc2ccccc2)NC(=O)[C@](O)(Cc2ccccc2)NC1=O</smiles>

26

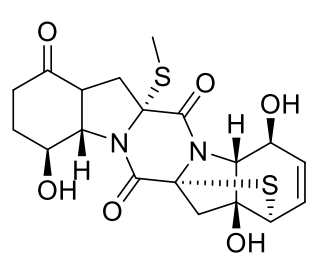

23

27

Fig. 3 Chemical structures of 16-27<smiles>[R20]C(Cc1ccc2[nH]c(C(C)(C)C=C)c(C=c3[nH]c(=O)[Y16]([H])([H])[nH]c3=O)c2c1)C([R20])(C)C</smiles><smiles></smiles><smiles>[R20]C(Cc1ccc2[nH]c(C(C)(C)C=C)c(C[C@H]3NC(=O)[C@@H](C)NC3=O)c2c1)C(C)(C)C</smiles>

$$
\begin{aligned}
& 28 \mathrm{R}_{1}=\mathrm{R}_{2}=\mathrm{H} \\
& 29 \mathrm{R}_{1}=\mathrm{Me}, \mathrm{R}_{2}=\mathrm{H} \\
& 30 \mathrm{R}_{1}=\mathrm{H}, \mathrm{R}_{2}=\mathrm{Ac}
\end{aligned}
$$

$31 \mathrm{R}=\mathrm{H}$

$32 \mathrm{R}=\mathrm{Me}$<smiles></smiles>

$33 \mathrm{R}_{1}=\mathrm{Me}, \mathrm{R}_{2}=\mathrm{H}$

$34 \mathrm{R}_{1}=\mathrm{H}, \mathrm{R}_{2}=\mathrm{Ac}$

$35 \mathrm{R}=\mathrm{H}$

$36 \mathrm{R}=\mathrm{Me}$

37<smiles>C=CC(C)(C)c1[nH]c2ccccc2c1/C=C1\NC(=O)[C@](CO)(OC)NC1=O</smiles>

38<smiles>C=CC(C)(C)c1[nH]c2ccc(C[C@H](O)C(C)(C)O)cc2c1/C=C1\NC(=O)C(=O)NC1=O</smiles>

39<smiles>[R]OC(c1c(C(C)(C)C=C)[nH]c2ccccc12)[C@H]1NC(=O)[C@@H](C)NC1=O</smiles>

$40 \mathrm{R}=\mathrm{H}$

$41 \mathrm{R}=\mathrm{Me}$<smiles>C=CC(C)(C)n1cc(C[C@@H]2NC(=O)[C@H](C)NC2=O)c2ccccc21</smiles>

42

Fig. 4 Chemical structures of $\mathbf{2 8 - 4 2}$ 
<smiles>COC/C(C)=C/C(=O)N1CCC[C@]2(CCCN(C(=O)/C=C(\C)CCO)C2=O)NC1=O</smiles>

43 (RR) (+)-pestaloxazine A 44 (SS) (-)-pestaloxazine A

Fig. 5 Chemical structures of $\mathbf{4 3 - 4 4}$

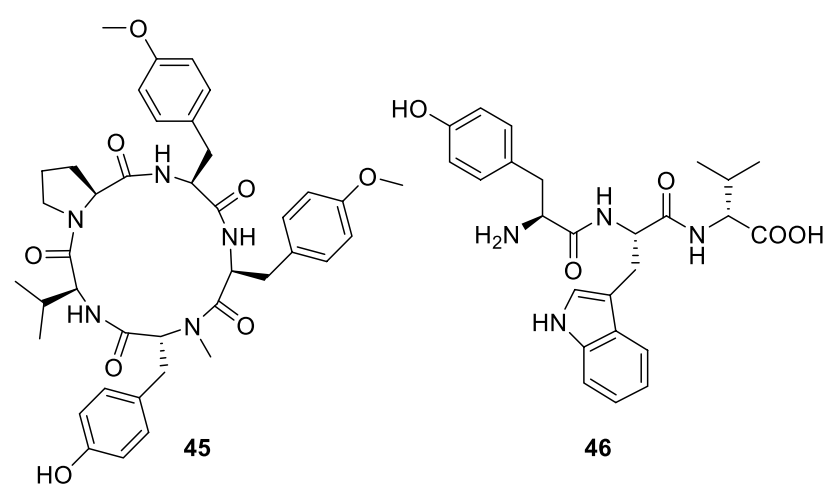

Fig. 6 Chemical structures of $45-46$

mixed polyketide-cyclo-dipeptide class of natural products (often referred to as a PKS-NRPS hybrid). According to the anti-EV71 assay in vitro, $\mathbf{4 3}, \mathbf{4 4}$, and their enantiomeric mixtures showed antiviral biological activity with $\mathrm{IC}_{50}$ values of $14.2 \pm 1.3,69.1 \pm 3.1$, and $16.0 \pm 0.8 \mu \mathrm{M}$, respectively. It is worth noting that the antiviral activity of $\mathbf{4 3}$ is about 18 -fold higher than that of ribavirin $\left(\mathrm{IC}_{50}=256.1 \pm 15.1 \mu \mathrm{M}\right)$. In addition, their selectivity index (SI) for anti-EV71 activity is different, indicating that the stereochemistry of the spiro center may contribute to the antiviral activity and selectivity indices. Pestaloxazine A has a unique structural skeleton

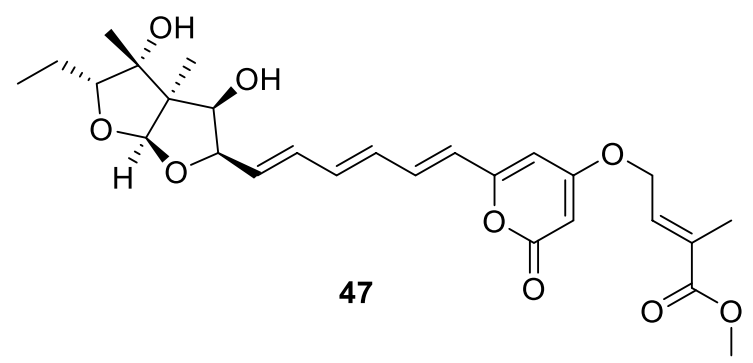

including its symmetric spiro [oxazinane-piper-azinedione] skeleton and two unique hemiaminal and oxazinane groups, and 10 of the 22 carbon atoms are oxygenation or nitrification which also contributes to the special structure.

Two linear peptides, namely aspergillipeptides $\mathrm{D}(\mathbf{4 5})$ and E (46) (Ma et al. 2017) (Fig. 6), were isolated from a culture broth of marine gorgonian-derived fungus Aspergillus sp. obtained from the China South Sea gorgonian Melitodes squamata. Compounds $\mathbf{4 5}$ and $\mathbf{4 6}$ showed evident antiviral activity against herpes simplex virus type 1 (HSV-1) with $\mathrm{IC}_{50}$ values of 9.5 and $19.8 \mu \mathrm{M}$ under their non-cytotoxic concentrations against a Vero cell line, respectively. In addition, $\mathbf{4 5}$ had antiviral activity against acyclovir-resistant clinical isolates of HSV-1-106 and HSV-1-153 at concentration of $12.5 \mu \mathrm{M}$ with about $50 \%$ inhibition rate.

\section{Polyketones}

Polyketones are a class of secondary metabolites produced by bacteria, fungi, plants, and animals. These substances are not necessary for the growth and development of organisms, but can be used for defense or intercellular communication. Asteltoxins E (47) and F (48) (Tian et al. 2015) (Fig. 7) discovered from marine-derived fungus Aspergillus sp. Compounds $\mathbf{4 7}$ and $\mathbf{4 8}$ showed significant activity against $\mathrm{H} 3 \mathrm{~N} 2$ with the prominent $\mathrm{IC}_{50}$ values of $6.2 \pm 0.08$ and 8.9 $\pm 0.3 \mu \mathrm{M}$, respectively. In addition, asteltoxin $\mathrm{E}$ also exhibited inhibitory activity against $\mathrm{H} 1 \mathrm{~N} 1$ with an $\mathrm{IC}_{50}$ value of $3.5 \pm 1.3 \mu \mathrm{M}$.

Pestalotiolide A (49) (Jia et al. 2015a) was a phthalide derivative obtained from marine-derived fungus Pestalotiopsis sp. Compared to the positive control ribavirin $\left(\mathrm{IC}_{50}=418.0 \mu \mathrm{M}\right), 49$ exhibited significant anti-EV71 activity in vitro with an $\mathrm{IC}_{50}$ value of $27.7 \mu \mathrm{M}$. Structure-activity relationships (SAR) indicated that the glycosidation of 7-OH significantly increased anti-EV71 activity and the acetylation of 6'-OH also increased anti-EV71 activity. The acetoxy group at C-6' had a positive contribution to anti-EV71 activity as well.

Isoprenylated cyclohexanols, truncateol M (50) (Zhao et al. 2015), was isolated from the solid culture of the<smiles>COC(=O)/C(C)=C/COc1cc(/C=C/C=C/C=C/C2O[C@@H]3O[C@H](C)[C@@](C)(O)[C@@]3(O)C2O)oc(=O)c1</smiles>

Fig. 7 Chemical structures of $\mathbf{4 7 - 4 8}$ 
sponge-associated fungus Truncatella angustata obtained from a finger sponge Amphimedon sp. collected from the bay of Yongxing Island in the South China Sea was fermented. The potential mechanism for $\mathbf{5 0}$ to suppress influenza infection by targeting virion assembly/release step to exert an effective inhibitory effect. The inhibitory effect of $\mathbf{5 0}$ on the H1N1 virus was almost six-fold more potent than OSV with an $\mathrm{IC}_{50}$ value of $8.8 \mu \mathrm{M}$ (oseltamivir (OSV) as positive control, $\mathrm{IC}_{50}=46.5 \mu \mathrm{M}$ ).

A new chromone, coniochaetone J (51) (Liu et al. 2017a) (Fig. 8), was isolated from deep-sea derived sediment fungus Penicillium sp. Compound $\mathbf{5 1}$ exhibited weak anti-EV71 activity in vitro with an $\mathrm{IC}_{50}$ value of $81.6 \mu \mathrm{M}$ (ribavirin as positive control, $\mathrm{IC}_{50}=0.6 \mu \mathrm{M}$ ).

A class of phenolic lactones, spiromastilactones B, D-G, I-J and L (52-59) (Niu et al. 2016) (Fig. 9), were isolated from a deep-sea derived fungus Spiromastix sp. An antiviral assay revealed that these compounds show inhibitory activity against WSN influenza virus with low cytotoxicity. Among them, $\mathbf{5 4}$ and $\mathbf{5 5}$ have strong antiviral activity, even higher than their positive control compounds (oseltamivir, $10.0 \mu \mathrm{M}$ and amantadine, $13.0 \mu \mathrm{M}$ ) with $\mathrm{IC}_{50}$ values of $6.0 \pm 0.2$ and $11.4 \pm 1.3 \mu \mathrm{M}$, respectively. The remaining compounds have weak antiviral activity against WSN influenza virus with $\mathrm{IC}_{50}$ values of $16.2 \pm 0.6,27.6 \pm 0.4,30.7 \pm 1.7,74.9 \pm 4.9,38.2 \pm 2.1$, and $22.6 \pm 0.9 \mu \mathrm{M}$, respectively. In addition, spiromastilactone $\mathrm{D}$ displayed the most potent activity by inhibiting a panel of influenza A and B viruses. Mechanistic studies indicated that spiromastilactone $\mathrm{D}$ binds to the hemagglutinin protein (HA) and disrupts the interaction of HA-sialic acid receptor, which is essential for the attachment and entry of all influenza viruses. In addition, $\mathbf{5 4}$ also showed modest inhibition on viral genome replication. These findings, in association with the inhibitory effects against a panel of influenza virus strains and less induction of drug resistance, suggested that the spiromastilactone entity may be an attracting scaffold for development of a new class of influenza virus inhibitors. Structure-activity relationships indicated that chlorination at either $3^{\prime}$ or $5^{\prime}$ or methylation of the 2'-hydroxyl group all enhanced the antiviral activity significantly. Simultaneous methylation of the 2 '-hydroxyl group and chlorination at either $3^{\prime}$ or 5 ' further enhance their potency against the WSN virus. However,

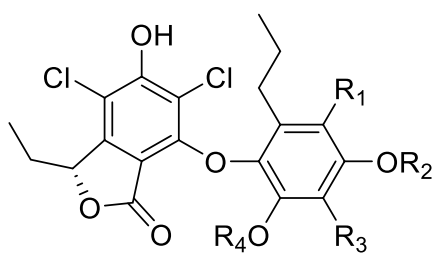

$52 \mathrm{R}_{1}=\mathrm{Cl}, \mathrm{R}_{2}=\mathrm{R}_{4}=\mathrm{Me}, \mathrm{R}_{3}=\mathrm{H}$ $53 \mathrm{R}_{1}=\mathrm{Cl}, \mathrm{R}_{2}=\mathrm{R}_{3}=\mathrm{H}, \mathrm{R}_{4}=\mathrm{Me}$ $54 \mathrm{R}_{1}=\mathrm{R}_{2}=\mathrm{H}, \mathrm{R}_{3}=\mathrm{Cl}, \mathrm{R}_{4}=\mathrm{Me}$ $55 \mathrm{R}_{1}=\mathrm{Cl}, \mathrm{R}_{2}=\mathrm{R}_{3}=\mathrm{R}_{4}=\mathrm{H}$ $56 \mathrm{R}_{1}=\mathrm{R}_{2}=\mathrm{R}_{4}=\mathrm{H}, \mathrm{R}_{3}=\mathrm{Cl}$ $57 \mathrm{R}_{1}=\mathrm{R}_{2}=\mathrm{R}_{3}=\mathrm{H}, \mathrm{R}_{4}=\mathrm{Me}$ $58 \mathrm{R}_{1}=\mathrm{R}_{3}=\mathrm{Cl}, \mathrm{R}_{2}=\mathrm{Me}, \mathrm{R}_{4}=\mathrm{H}$ $59 \mathrm{R}_{1}=\mathrm{R}_{3}=\mathrm{Cl}, \mathrm{R}_{2}=\mathrm{H}, \mathrm{R}_{4}=\mathrm{Me}$

Fig. 9 Chemical structures of $\mathbf{5 2 - 5 9}$

chlorination at both $3^{\prime}$ and $5^{\prime}$ with the $2^{\prime}$-hydroxyl group either methylated or not decreased substantially the antiviral activity. Further, methylation of the 2'-hydroxyl group seems likely to be critical since the methylated derivatives were all more potent than their parent compounds. In contrast, methylation of $4{ }^{\prime}$-hydroxyl group seems detrimental to the antiviral activity. Clearly, mono-methylation and mono-chlorination rather than di-methylation and/or dichlorination of spiromastilactone promoted the antiviral activity, $\mathbf{5 4}$ exerting the most potent.

Two phenolic polyketides, wailupemycin $\mathbf{J}(\mathbf{6 0})$ and $R$-Wailupemycin $\mathrm{K}(\mathbf{6 1})$ were isolated and identified from the fermentation broth of Streptomyces sp. associated with the marine green algae, Enteromorpha prolifera (Liu et al. 2017b). Compounds $\mathbf{6 0}$ and $\mathbf{6 1}$ at a concentration of $50 \mu \mathrm{g} / \mathrm{mL}$ showed anti-H1N1 virus activity with $47.8 \%$ and $42.5 \%$ inhibitions, respectively (positive control ribavirin, $45.3 \%$ inhibition). Regrettably, the $\mathrm{IC}_{50}$ values of $\mathbf{6 0}$ and 61 were not obtained due to the lack of quantity.

Abyssomicin monomers designated neoabyssomicin D (62) (Huang et al. 2018) (Fig. 10) was discovered from the marine-derived Streptomyces koyangensis. Compound 62 exhibited mild antiviral activity against herpes simplex virus at a concentration of $10 \mu \mathrm{M}$, the percentage of virus replication is low $(31 \pm 10 \%)$. Structurally as a representative of a novel abyssomicin skeleton, $\mathbf{6 2}$ contains a unique $8 / 5 / 5 / 7$ tetracyclic core. The biosynthetic pathway may be that the internal Michael addition reaction at C-16 of abyssomicin 4 with the enolate formed by deprotonation at C-8 would yield abyssomicin 5 (Leon et al. 2015). The hydroxy group at C-9 can be eliminated in tandem with the cleavage of the $\mathrm{C}-10 / \mathrm{C}-11$ bond, leading to the generation of the intermediate with a C-9/C-10 double bond. An aldol

Fig. 8 Chemical structures of 49-51<smiles>COc1c(C)c2c(c(O[C@H]3C[C@H](O)[C@H](O)[C@H](COC(C)=O)O3)c1C)C(=O)OC2</smiles>

49<smiles>CC1(C)CC(=O)C2=C(O1)[C@H](Cl)[C@]1(O)C[C@@H](C(C)(C)O)O[C@H]1C2</smiles>

50<smiles>COC(=O)c1cc(O)c2c(c1)OC1CCC(OC)C1C2=O</smiles>

51 
Fig. 10 Chemical structures of 60-62

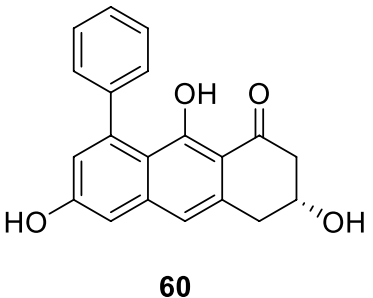<smiles>[R]Oc1c([R2])c(C)c([R3])c2oc3cc(O)cc(C([R])=O)c3c(=O)c12</smiles><smiles>CC(=O)c1c(O)cc2c3c(cccc13)C=C(C[C@H](C)O)O2</smiles>

61<smiles>COc1cc(CCCC(C)C)oc(=O)c1C</smiles>

69

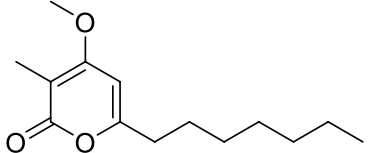

71

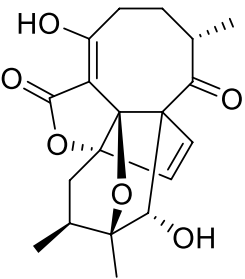

62

Fig. 11 Chemical structures of 63-68

reaction between a C-8 enolate and C-11 yields a new seven-membered ring to give this compound.

\section{Pyrones}

Pyrones are a class of heterocyclic chemical compounds. They contain an unsaturated six-membered ring with one oxygen atom and a ketone functional group. There are two isomers denoted as 2-pyrone and 4-pyrone. Methyl(2-chloro-1,6-dihydroxy-3-methylxanthone)-8-carboxylate (63), methyl-(4-chloro-1,6-dihydroxy-3-methylxanthone)8-carboxylate (64), methyl-(4-chloro-6-hydroxy-1-methoxy-3-methylxanthone)-8-carboxylate (65), methyl-(6-hydroxy-1-methoxy-3-methylxanthone)-8-carboxylate (66), 4-chloro-1,6-dihydroxy-3-methylxanthone-8-carboxylic acid (67), and 2,4-dichloro-1,6-dihydroxy-3-methylxanthone-8-carboxylic acid (68) (Kang et al. 2018) (Fig. 11) were isolated from the coastal saline soil-derived Aspergillus iizukae by application of an OSMAC approach. Compound 64 exhibited strong antiviral activities against H1N1, HSV1 , and HSV-2 with $\mathrm{IC}_{50}$ values of $44.6,21.4$, and $76.7 \mu \mathrm{M}$, respectively (ribavirin as the positive controls of $\mathrm{H} 1 \mathrm{~N} 1$ and acyclovir as the positive control of HSV-1 and HSV-2). The preliminary structure-activity relationships of 63-68 showed that the hydroxy group at C-1 and the methyl carboxylate group at C-8 essentially contributed to the anti-H1N1, antiHSV-1, and anti-HSV-2 activities, and the position of the chlorine atom in ring A would affect the antiviral activities. Additionally, it seemed that methylation of the hydroxy group at $\mathrm{C}-1$ or replacement of methyl carboxylate at $\mathrm{C}-8$ by carboxylic acid, to a large extent, lower the antiviral effect.

Heterologous expression of the type III polyketide synthase (PKS) gene vioA in marine-derived Streptomyces youssoufiensis led to production of violapyrones (VLPs) Q-T (69-72) (Hou et al. 2018) (Fig. 12). Besides, 69-72
Fig. 12 Chemical structures of 69-72

showed anti-H1N1 activity with $\mathrm{IC}_{50}$ values of 58.8, 64.9, 30.6, and 68.4 $\mu \mathrm{M}$, respectively. Compounds 69-72 also revealed anti-H3N2 activity with $\mathrm{IC}_{50}$ values of 95.0, 63.9, 45.3 , and $72.8 \mu \mathrm{M}$, respectively. Preliminary structure-activity relationships research demonstrated that all the methylated compounds displayed stronger anti-virus activity than their non-methylated counterparts, among which $\mathbf{7 1}$ showed the best activities. Methylation of 4-OH has a negative effect on the anti-MRSA (methicillin-resistant Staphylococcus aureus) activity, with methylated VLPs displaying decreased (70) or abolished (71 and 72) activities in comparison with each of their non-methylated counterparts. Results suggested that methylation at 4-OH of these compounds enhanced antivirus activity but reduced anti-MRSA activity.

\section{Sterols}

Sterols, also known as steroid alcohols, are a subgroup of the steroids and an important class of organic molecules. They occur naturally in plants, animals, and fungi, and can be also produced by some bacteria. A new pregnane, $3 \alpha$-hydroxy-7ene-6,20-dione (73) (Yu et al. 2017) was obtained from the fungus Cladosporium sp. cultured from a gorgonian Dichotella gemmacea collected from the South China Sea. This compound has a rare configuration of $3 \alpha-\mathrm{OH}$ that is different from most of pregnanes. Compound $\mathbf{7 3}$ showed antiviral activity against the respiratory syncytial virus (RSV) with 
the $\mathrm{IC}_{50}$ value of $0.12 \mu \mathrm{M}$. Cladosporisteroid B (74) (Pang et al. 2018), a highly oxygenated sterol, was also isolated from the culture extracts of sponge-derived fungus Cladosporium sp. and exhibited weak inhibitory activity against $\mathrm{H} 3 \mathrm{~N} 2$ with an $\mathrm{IC}_{50}$ value of $16.2 \mu \mathrm{M}$.

A new ergostane analogue, $3 \beta$-hydroxyergosta8,14,24(28)-trien-7-one (75) (Li et al. 2019b) (Fig. 13), was isolated and characterized from the marine-derived fungus Penicillium sp. IMB17-046. Compound 75 displayed broad-spectrum antiviral activities against different types of viruses, showed anti-HIV activity with an $\mathrm{IC}_{50}$ value of $3.5 \mu \mathrm{M}$ and potent anti-IAV activity with an $\mathrm{IC}_{50}$ value of $0.5 \mu \mathrm{M}$, that is 300 -fold stronger than ribavirin.

\section{Terpenoids}

Terpenoids are volatile substances distributed in the animal and plant kingdom, especially in essential oils of plants, and are important chemical components of natural medicine. Talaromyolide D (76) (Cao et al. 2019) was isolated from a marine fungus Talaromyces sp. Compound $\mathbf{7 6}$ displayed potent antiviral activity against pseudorabies virus (PRV) with a $\mathrm{CC}_{50}$ value of $3.35 \mu \mathrm{M}$.

Two new meroterpenoids, chrodrimanins K (77) and N (78) (Kong et al. 2017) were discovered from the fermentation broth of Penicillium sp. collected from a marine worm of Haikou Bay, China. Compounds $\mathbf{7 7}$ and $\mathbf{7 8}$ displayed anti-H1N1 activity with $\mathrm{IC}_{50}$ values of 74 and $58 \mu \mathrm{M}$, respectively.

A new meroterpenoid, stachybonoid A (79) (Zhang et al. 2017), was discovered from the crinoid-derived fungus Stachybotrys chartarum, a crinoid (Himerometra magnipinna) isolated from Xuwen Coral Reef Nature Reserve, Zhanjiang city, Guangdong Province, China. Compound 79 displayed inhibitory activity against the replication of dengue virus (DENV). Biosynthetically, orsellinic acid and farnesyl diphosphate underwent addition to form the intermediate ilicicolin B. Then, the terminal olefin bond in the prenyl group of ilicicolin B was epoxidized to obtain another intermediate. When the aromatic hydroxyl group was connected to the $\mathrm{C}-3$ of the prenyl group by electrophilic addition, $\mathbf{7 9}$ was obtained.

Stachybogrisephenone B (80) (Qin et al. 2014) (Fig. 14) was discovered from the cultures of sponge-derived fungus Stachybotry sp. Compound $\mathbf{8 0}$ showed activity against intestinal virus EV71 with an $\mathrm{IC}_{50}$ value of $30.1 \mu \mathrm{M}$ (ribavirin as positive control, $\mathrm{IC}_{50}=0.60 \mu \mathrm{M}$ ).

\section{Others}

Isoprenylated cyclohexanols, truncateols $\mathrm{C}(\mathbf{8 1}), \mathrm{E}(\mathbf{8 2})$ (Zhao et al. 2015), O (83) and P (84) (Zhao et al. 2018), were isolated from the marine-derived fungus Truncatella angustata collected from the South China Sea. Compounds $\mathbf{8 1}$ and $\mathbf{8 2}$ showed anti-H1N1 activities with $\mathrm{IC}_{50}$ values of 55 and $63.5 \mu \mathrm{M}$, respectively (the $\mathrm{IC}_{50}$ value of the positive control, oseltamivir was $46.5 \mu \mathrm{M}$ ). Compound 83 exhibited significant inhibition toward both HIV-1 and H1N1 virus with $\mathrm{IC}_{50}$ values of $39.0 \pm 1.2$ and $30.4 \pm 0.4 \mu \mathrm{M}$, respectively. Compound 84 showed anti-HIV-1 activity with an $\mathrm{IC}_{50}$ value of $16.1 \pm 0.7 \mu \mathrm{M}$. Due to lower cytotoxicity $\left(\mathrm{CC}_{50}>100 \mu \mathrm{M}\right)$, these compounds could be considered as potential anti-HIV lead compounds in comparison with the positive control efavirenz $\left(\mathrm{CC}_{50}>40.6 \mu \mathrm{M}\right)$.

A hexahydrobenzopyran derivative, cytosporin L (85) (Liao et al. 2017), was isolated from the marine-derived fungus Eutypella sp. collected from the South China Sea. Compound $\mathbf{8 5}$ obviously inhibited the respiratory syncytial virus (RSV) with the $\mathrm{IC}_{50}$ value of $72.01 \mu \mathrm{M}$ (ribavirin as positive control).

New salicyloid derivative, vaccinol J (86) (Wang et al. 2017), was discovered from Pestalotiopsis vaccinii endogenous with the mangrove plant Kandelia candel (L.) Druce (Rhizophoraceae). Compound 86 was a salicyloid derivative that containing 2-methylfuran moiety and

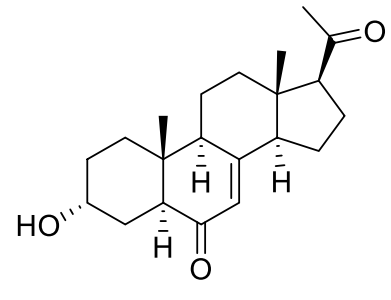

73

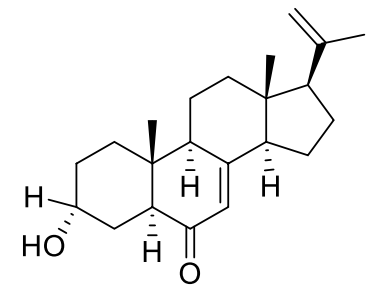

74<smiles>C=C(CC[C@@H](C)C1CC=C2C3=C(CC[C@]21C)[C@@]1(C)CC[C@@H](O)C[C@]1(C)CC3=O)C(C)C</smiles>

75

Fig. 13 Chemical structures of 73-75 


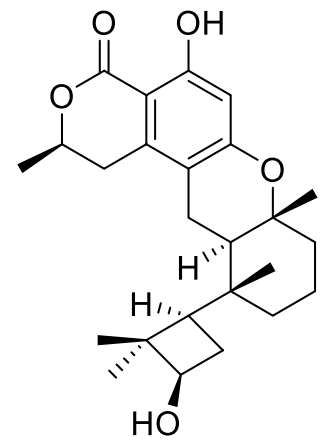

76<smiles>C[C@H]1c2c3c(c(Cl)c(O)c2C(=O)O[C@@H]1C)[C@H](O)C[C@H](C)[C@]1(C)C=CC(=O)C(C)(C)[C@H]1C3</smiles>

77

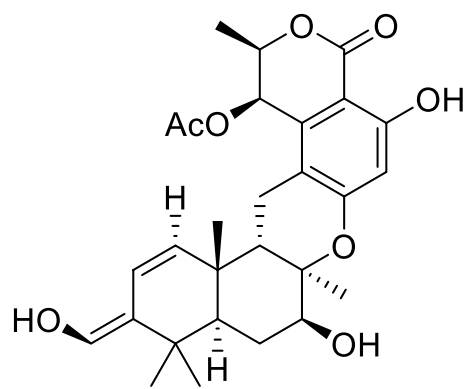

78<smiles>COC(C)(C)[C@H](O)CC/C(C)=C\CC[C@]1(C)C=Cc2c(O)cc(COC(C)=O)c(C=O)c2O1</smiles>

79<smiles>COc1cc(C)c(C(=O)c2c(O)cc(OC)c(Cl)c2O)c(O)c1</smiles>

80

Fig. 14 Chemical structures of 76-80

showed anti-enterovirus 71 (EV71) activity in vitro with an $\mathrm{IC}_{50}$ value of $30.7 \mu \mathrm{M}$ (ribavirin as positive control, $\left.\mathrm{IC}_{50}=177.0 \mu \mathrm{M}\right)$.

A new citrinin monomer, namely penicitrinol L (87) (Yang et al. 2018), was discovered from the extracts of the coculture of two marine algal-derived endophytic fungal strains Aspergillus sydowii and Penicillium citrinum. Compound 87 has the influenza neuraminidase $(\mathrm{H} 5 \mathrm{~N} 1)$ inhibitory activity in vitro with an $\mathrm{IC}_{50}$ value of $41.5 \mu \mathrm{M}$.

A new anthranilic acid, anthranoside $\mathrm{C}(\mathbf{8 8})$ (Che et al. 2018), was isolated from a marine sponge-derived actinomycete Streptomyces sp. Compound $\mathbf{8 8}$ possessed a unique indole-containing scaffold and showed anti-influenza H1N1 virus activity with an $\mathrm{IC}_{50}$ value of $171 \mu \mathrm{M}$ (ribavirin as positive control, $\mathrm{IC}_{50}=133 \mu \mathrm{M}$ ). Biosynthetically, the compound may derive from an assembly by ATA and D-glucose. Structurally, $\mathbf{8 8}$ was comprised of ATA moiety and polyol units.

A new butenolide derivative, (4S)-10-hydroxy-10-methyl-11-oxo-dodec-2-en-1,4-olide (89) (Huang et al. 2019) (Fig. 15), was isolated from marine-derived Streptomyces koyangensis. Compound $\mathbf{8 9}$ displayed mild antiviral activity against herpes simplex virus with an $\mathrm{EC}_{50}$ value of $25.4 \mu \mathrm{M}$, which was characterized by an octyl substitution on C-position.

\section{Conclusions and outlooks}

The explosive growth of global drug resistance has prompted drug research and development institutions to actively seek new antiviral drugs, especially the recent global outbreak of new coronary pneumonia, which has promoted enthusiasm for antiviral drug research unprecedented. Although there are many challenges in the exploration and development of marine microorganisms, many significant antiviral activity compounds have been obtained from marine microorganisms, and it is expected that marine microorganisms will continue to be a good source of antiviral drugs, especially the novel, highly effective, low-toxic antiviral natural products.

This review surveys natural products systematically with antiviral activity derived from marine microorganisms, and clarifies the antiviral activities of these compounds 
<smiles>C=C(C)C#CC1=C[C@@H]2OC(C)(C)[C@@H](O)C[C@]23O[C@@H]3[C@@H]1O</smiles>

81<smiles>C=C(C)C#CC1=C[C@H]2O[C@H](C(C)(C)O)C[C@]2(O)[C@H]2O[C@H]12</smiles>

84<smiles>Cc1c(O)cc(O)c2c1[C@H](C)[C@H](C)O[C@H]2CC(=O)O</smiles>

87<smiles>C=C(C)C=C=C1C[C@H]2O[C@@H](C(C)(C)O)C[C@]23O[C@H]3[C@@H]1O</smiles>

82<smiles>CCCCC/C=C/C1=C(CO)[C@@H]2OC(C)(C)[C@@H](O)C[C@]2(O)C[C@H]1O</smiles>

85<smiles>O=C(O)c1ccccc1Nc1c(C[C@H](O)[C@H](O)CO)[nH]c2c(C(=O)O)cccc12</smiles>

88<smiles>C=C(C)C#CC1=C[C@H]2O[C@H](C(C)(C)O)C[C@]2(O)[C@@H]2O[C@H]12</smiles>

83<smiles>CC(C)=CCc1ccc(O)c(CO)c1-c1ccc(C)o1</smiles>

86<smiles>CC(=O)C(C)(O)CCCCC[C@H]1C=CC(=O)O1</smiles>

89

Fig. 15 Chemical structures of 81-89

and related research progresses. In the literature spanning 2015-2019, marine microbial-derived natural products have made important progress in the study of antiviral lead compounds. A total of 89 secondary metabolites have been found, of which more than 30 have potent antiviral activities. Two secondary metabolites, trypilepyrazinol (6) and $3 \beta$-hydroxyergosta-8,14,24(28)-trien-7-one (75) showed potent broad-spectrum (HIV, HCV) antiviral activities worthy of further study (Table 1). Many significant antiviral activity compounds have been obtained from marine microorganisms, and it is expected that marine microorganisms will continue to be a good source of antivirals. The biological profiles of these leads provide hope for the discovery of highly effective and low-toxicity agents.

The antiviral compounds derived from marine microorganisms described herein can be divided into 8 biosynthetic categories; alkaloids, quinones, peptides, polyketones, pyrones, sterols, terpenoids and others (Fig. 16). Among them, peptides are the most group of secondary metabolites with potentially useful activities. Figure 17 shows that 10 viruses including H1N1, HIV, HSV, H3N2, EV71, $\mathrm{HCV}, \mathrm{RSV}, \mathrm{H} 5 \mathrm{~N} 1, \mathrm{HBV}$ and DENV were used as screening viruses for the antiviral activities of the compounds. In addition, most antiviral compounds showed anti-H1N1 activity, followed by anti-HIV and anti-HSV activities. Only one compound exhibited anti-DENV activity. Truncateol M (50) showed potent anti-H1N1 activity, eutypellazines E (20), I-K (24-27) and 3 $\beta$-hydroxyergosta-8,14,24(28)-trien-7-one (75) exhibited promising anti-HIV activity, trichobotrysins A (1) and D (3), aspergilols H (10) and I (11) had strong anti-HSV activity. Asteltoxins E (47) and F (48) showed anti-H3N2 activity, trypilepyrazinol (6), raistrickindole A (7) and raistrickin (8) exhibited potent anti-HCV activity. These provide guidance for the later screening of antiviral activity of new compounds.

In summary, marine natural products are an important source of discovery of lead compounds and drug candidates for antiviral drugs. Nevertheless, it is undeniable that the current research and development of marine natural products still face bottlenecks. First, it is difficult to 
Table 1 Recent progresses in marine-derived antiviral natural products

\begin{tabular}{|c|c|c|c|c|}
\hline \multirow[t]{2}{*}{ Type } & \multirow[t]{2}{*}{ No } & \multirow[t]{2}{*}{ Source } & \multicolumn{2}{|c|}{ Active compound } \\
\hline & & & No & Level \\
\hline \multirow[t]{5}{*}{ Alkaloids } & 1-3 & Trichobotrys effuse & 1-3 & POTENT (HSV-1) \\
\hline & 4,5 & Neosartorya udagawae & 4,5 & Moderate (H1N1) \\
\hline & 6 & Penicillium sp. & 6 & Potent (HIV, HCV) \\
\hline & 7,8 & Penicillium raistrickii & 7,8 & Potent (HCV) \\
\hline & 9 & Streptomyces fradiae strain VITMK2 & 9 & Potent (WSSV) \\
\hline \multirow[t]{6}{*}{ Quinones } & 10,11 & Aspergillus versicolor & 10,11 & Significant (HSV-1) \\
\hline & 12 & Aspergillus sydowii and Penicillium citrinum & 12 & Weak (H5N1) \\
\hline & 13,14 & Penicillium sp. & 13 & Potent (HBV) \\
\hline & & & 14 & Significant (HBV) \\
\hline & 15 & Nocardia alba KC710971 & 15 & Moderate (NDV) \\
\hline & & & & Moderate (IBDV) \\
\hline \multirow[t]{4}{*}{ Peptides } & 16-27 & Eutypella sp. & $16-27$ & Significant (HIV-1) \\
\hline & $28-42$ & Eurotium rubrum & $28-42$ & Weak (H1N1) \\
\hline & 43,44 & Pestalotiopsis sp. & 43,44 & Potent (EV71) \\
\hline & 45,46 & Aspergillus sp. & 45,46 & Potent (HSV-1) \\
\hline \multirow[t]{10}{*}{ Polyketones } & 47 & Aspergillus sp. & 47 & Potent (H3N2, H1N1) \\
\hline & 48 & Aspergillus sp. & 48 & Potent (H3N2) \\
\hline & 49 & Pestalotiopsis sp. & 49 & Potent (EV71) \\
\hline & 50 & Truncatella angustata & 50 & Potent (H1N1) \\
\hline & 51 & Penicillium sp. & 51 & Weak (EV71) \\
\hline & $52-59$ & Spiromastix sp. & $52-54$ & Strong (H1N1) \\
\hline & & & $55,56,58,59$ & Moderate (H1N1) \\
\hline & & & 57 & Weak (H1N1) \\
\hline & 60,61 & Streptomyces sp. & 60,61 & Moderate (H1N1) \\
\hline & 62 & Streptomyces koyangensis & 62 & Low (HSV) \\
\hline \multirow[t]{6}{*}{ Pyrones } & $63-68$ & Aspergillus iizukae & 63 & Potent (HSV-1) \\
\hline & & & & Weak (H1N1, HSV-2) \\
\hline & & & 64 & Potent (H1N1, HSV-1, HSV-2) \\
\hline & & & $65,67,68$ & Weak HSV-1 \\
\hline & & & 66 & Weak (HSV-1, HSV-2) \\
\hline & $69-72$ & Streptomyces youssoufiensis & $69-72$ & Moderate (H1N1, H3N2) \\
\hline \multirow[t]{3}{*}{ Sterols } & 73,74 & Cladosporium sp. & 73 & Potent (RSV) \\
\hline & & & 74 & Weak (H3N2) \\
\hline & 75 & Penicillium sp. & 75 & Potent (HIV, IAV) \\
\hline \multirow[t]{4}{*}{ Terpenoids } & 76 & Talaromyces sp. & 76 & Potent (PRV) \\
\hline & 77-78 & Penicillium sp. & 77-78 & Weak (H1N1) \\
\hline & 79 & Stachybotrys chartarum & 79 & Significant (DENV) \\
\hline & 80 & Stachybotry sp. & 80 & Moderate (EV71) \\
\hline \multirow[t]{9}{*}{ Others } & $81-84$ & Truncatella angustata & 81,82 & Moderate (H1N1) \\
\hline & & & 83 & Potent (H1N1) \\
\hline & & & & Weak (HIV) \\
\hline & & & 84 & Weak (HIV) \\
\hline & 85 & Eutypella sp. & 85 & Moderate (RSV) \\
\hline & 86 & Pestalotiopsis vaccinii & 86 & Moderate (EV71) \\
\hline & 87 & Aspergillus sydowii and Penicillium citrinum & 87 & Weak (H5N1) \\
\hline & 88 & Streptomyces sp. & 88 & Low (H1N1) \\
\hline & 89 & Streptomyces koyangensis & 89 & Mild (HSV) \\
\hline
\end{tabular}




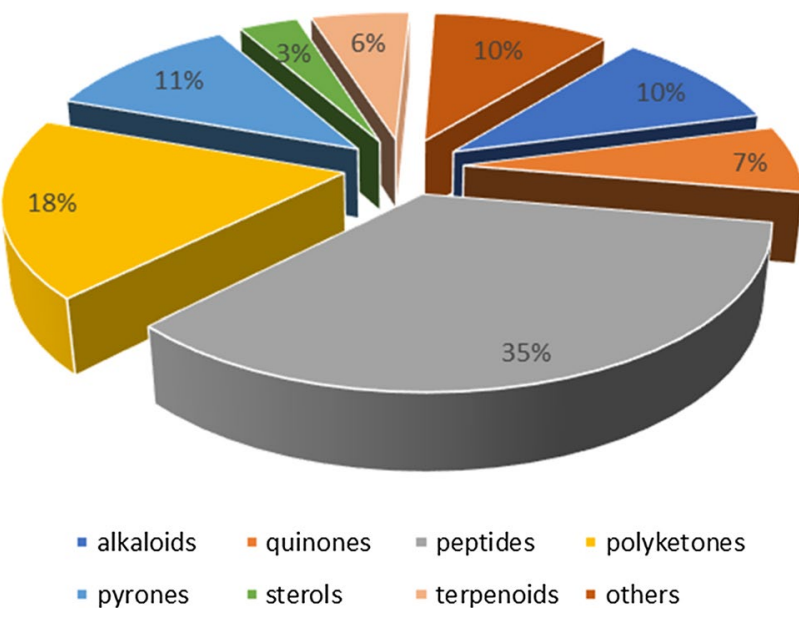

Fig. 16 The type of marine microbial-derived antiviral compounds

apply screening techniques to obtain lead compounds. Second, it is difficult to fully synthesize complex marine natural products. The most important thing is that most active marine natural products are limited to in vitro cell experiments, and few animals in vivo and clinical trials because of the limited availability of natural products. Today's rapidly evolving technologies and an increasing understanding of the molecular processes and mechanisms of secondary metabolite production will continue to increase the possibility of extracting natural products from marine microorganisms. By using marine natural product compound libraries and computing virtual screening can quickly obtain good active lead compounds; explore the synthetic route of complex products by fusing artificial intelligence technology with the total synthesis of natural products; finally, promote the activity evaluation of highactivity and low-toxic natural products and conduct animal experiments.

The purpose of this review is to help interested readers understand the current status of marine-derived antiviral compounds, and in the process identify areas for further research that may accelerate the development of more effective and selective drugs to treat this global disease.

Acknowledgements This Paper is Dedicated to Professor Youyou Tu, the 2015 Nobel Prize Laureate of Physiology or Medicine on the Occasion of Her 90th Birthday. This work was supported by the Program of National Natural Science Foundation of China (Grant Nos. U1706210, 41906090, and 41776141), the Program of Natural Science Foundation of Shandong Province of China (Grant No. ZR2019BD047), the Fundamental Research Funds for the Central Universities (No. 201841004), the Marine S\&T Fund of Shandong Province for Pilot National Laboratory for Marine Science and Technology (Qingdao) (Grant No. 2018SDKJ0403-2), the Taishan Scholars Program, China (Grant No. tsqn20161010).

\section{Compliance with Ethical Standards}

Conflict of interest The authors declared no conflict of interest.

\section{References}

Avilala J, Kumar AP, Viswanath B, Gopal DVRS, Narasimha G (2018) Antiviral and larvicidal properties of novel bioactive compounds produced from marine actinomycetes. Russ J Mar Biol 44:424 428. https://doi.org/10.1134/S106307401805005X

Barlow A, Landolf KM, Barlow B, Yeung SYA, Heavner JJ, Claassen CW, Heavner MS (2020) Review of emerging pharmacotherapy for the treatment of coronavirus disease 2019. Pharmacotherapy 40:416-437. https://doi.org/10.1002/phar.2398

Bhadury P, Mohammad BT, Wright PC (2006) The current status of natural products from marine fungi and their potential as
Fig. 17 Marine microbialderived compounds with antiviral activity

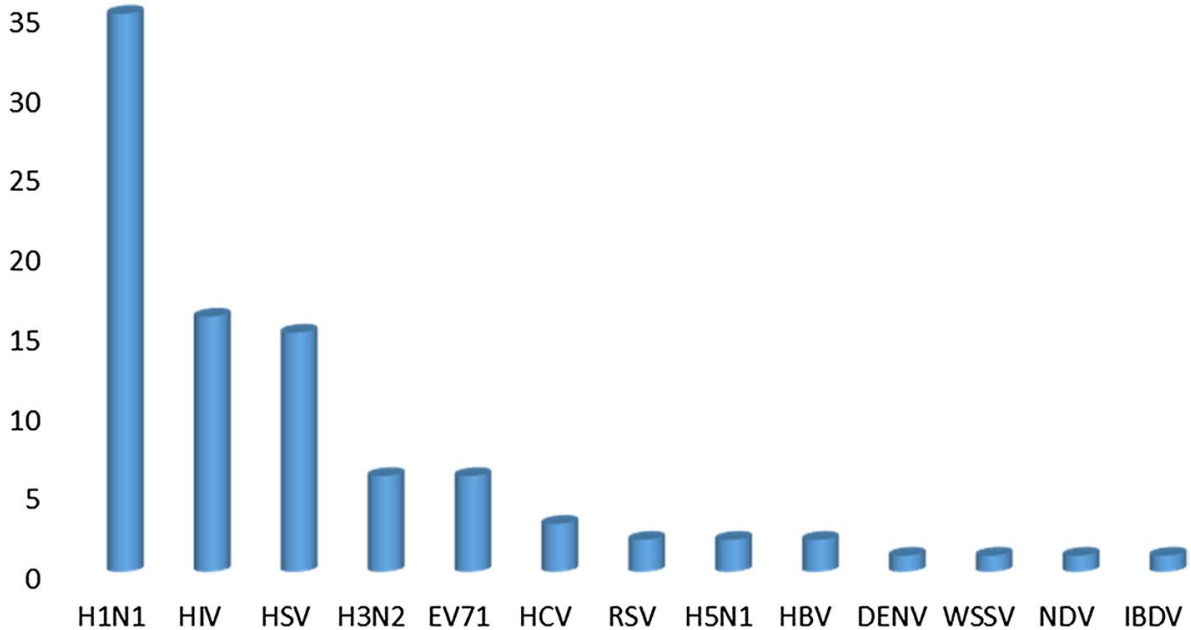


anti-infective agents. J Ind Microbiol Biotechnol 33:325-337. https://doi.org/10.1007/s10295-005-0070-3

Cao X, Shi Y, Wu X, Wang K, Huang S, Sun H, Dickschat JS, Wu B (2019) Talaromyolides A-D and talaromytin: polycyclic meroterpenoids from the fungus Talaromyces sp. CX11. Org Lett 21:6539-6542. https://doi.org/10.1021/acs.orglett.9b02466

Che Q, Qiao L, Han X, Liu Y, Wang W, Gu Q, Zhu T, Li D (2018) Anthranosides A-C, anthranilate derivatives from a spongederived Streptomyces sp. CMN-62. Org Lett 20:5466-5469. https ://doi.org/10.1021/acs.orglett.8b02382

Chen X, Si L, Liu D, Proksch P, Zhang L, Zhou D, Lin W (2015) Neoechinulin B and its analogues as potential entry inhibitors of influenza viruses, targeting viral hemagglutinin. Eur J Med Chem 93:182-195. https://doi.org/10.1016/j.ejmech.2015.02.006

Deshmukh SK, Prakash V, Ranjan N (2017) Marine fungi: a source of potential anticancer compounds. Front Microbiol 8:2536. https:// doi.org/10.3389/fmicb.2017.02536

Dolezal M, Zitko J (2012) Pyrazine derivatives: a patent review. Expert Opin Ther Pat 22:1033-1051. https://doi.org/10.1517/13543 776.2014 .982533

Goh VS, Mok CK, Chu JJ (2020) Antiviral natural products for arbovirus infections. Molecules 25:2796. https://doi.org/10.3390/molec ules 25122796

Henning H-G, Gelbin A (1993) Advances in tetramic acid chemistry. Adv Heterocycl Chem 57:139-185. https://doi.org/10.1016/S0065 $-2725(08) 60888-0$

Hermawan I, Higa M, Hutabarat PUB, Fujiwara T, Akiyama K, Kanamoto A, Haruyama T, Kobayashi N, Higashi M, Suda S, Tanaka J (2019) Kabirimine, a new cyclic imine from an okinawan dinoflagellate. Mar Drugs 17:353-361. https://doi.org/10.3390/md170 60353

Hou L, Wang S, Huang H, Li H, Wang W, Li W (2018) Generation of methylated violapyrones with improved anti-influenza A virus activity by heterologous expression of a type III PKS gene in a marine Streptomyces strain. Bioorg Med Chem Lett 28:28652868. https://doi.org/10.1016/j.bmcl.2018.07.029

Hou XM, Wang CY, Gerwick WH, Shao CL (2019) Marine natural products as potential anti-tubercular agents. Eur J Med Chem 165:273-292. https://doi.org/10.1016/j.ejmech.2019.01.026

Huang Z, Nong X, Ren Z, Wang J, Zhang X, Qi S (2017) Anti-HSV-1, antioxidant and antifouling phenolic compounds from the deep-sea-derived fungus Aspergillus versicolor SCSIO 41502. Bioorg Med Chem Lett 27:787-791. https://doi.org/10.1016/j. bmcl.2017.01.032

Huang H, Song Y, Li X, Wang X, Ling C, Qin X, Zhou Z, Li Q, Wei X, Ju J (2018) Abyssomicin monomers and dimers from the marine-derived Streptomyces koyangensis SCSIO 5802. J Nat Prod 81:1892-1898. https://doi.org/10.1021/acs.jnatprod.8b00448

Huang H, Song Y, Zang R, Wang X, Ju J (2019) Octyl substituted butenolides from marine- derived Streptomyces koyangensis. Nat Prod Res 5:1-6. https://doi.org/10.1080/14786419.2019.1686368

Jia Y-L, Guan F-F, Ma J, Wang C-Y, Shao C-L (2015) Pestalotiolide A, a new antiviral phthalide derivative from a soft coral-derived fungus Pestalotiopsis sp. Nat Prod Sci 21:227-230. https://doi. org/10.20307/nps.2015.21.4.227

Jia Y-L, Wei M-Y, Chen H-Y, Guan F-F, Wang C-Y, Shao C-L (2015) $(+)$ - and (-)-Pestaloxazine A, a pair of antiviral enantiomeric alkaloid dimers with a symmetric spiro[oxazinane-piperazinedione]skeleton from Pestalotiopsis sp. Org Lett 17:4216-4219. https ://doi.org/10.1021/acs.orglett.5b01995

Jin Y, Qin S, Gao H, Zhu G, Wang W, Zhu W, Wang Y (2017) An anti-HBV anthraquinone from aciduric fungus Penicillium sp. OUCMDZ-4736 under low pH stress. Extremophiles 22:39-45. https://doi.org/10.1007/s00792-017-0975-6

Kang H-H, Zhang H-B, Zhong M-J, Ma L-Y, Liu D-S, Liu W-Z, Ren H (2018) Potential antiviral Xanthones from a coastal saline soil fungus Aspergillus iizukae. Mar Drugs 16:449-457. https://doi. org/10.3390/md16110449

Kelecom A (2002) Secondary metabolites from marine microorganisms. An Acad Bras Cienc 74:151-170. https://doi.org/10.1590/ S0001-37652002000100012

Khan MT, Ali A, Wang Q, Irfan M, Khan A, Zeb MT, Zhang YJ, Chinnasamy S, Wei DQ (2020) Marine natural compounds as potents inhibitors against the main protease of SARS-CoV-2-a molecular dynamic study. J Biomol Struct Dyn. https://doi. org/10.1080/07391102.2020.1769733

Kong F-D, Ma Q-Y, Huang S-Z, Wang P, Wang J-F, Zhou L-M, Yuan J-Z, Dai H-F, Zhao Y-X (2017) Chrodrimanins K-N and related meroterpenoids from the fungus Penicillium sp. SCS-KFD09 isolated from a marine worm, Sipunculus nudus. J Nat Prod 80:10391047. https://doi.org/10.1021/acs.jnatprod.6b01061

Leon B, Navarro G, Dickey BJ, Stepan G, Tsai A, Jones GS, Morales ME, Barnes T, Ahmadyar S, Tsiang M, Geleziunas R, Cihlar T, Pagratis N, Tian Y, Yu H, Linington RG (2015) Abyssomicin 2 reactivates latent HIV-1 by a PKC- and HDAC- independent mechanism. Org Lett 17:262-265. https://doi.org/10.1021/ol503 $349 y$

Li G, Kusari S, Spiteller M (2014) Natural products containing 'decalin' motif in microorganisms. Nat Prod Rep 31:1175-1201. https://doi. org/10.1039/c4np00031e

Li J, Hu Y, Hao X, Tan J, Li F, Qiao X, Chen S, Xiao C, Chen M, Peng Z, Gan M (2019) Raistrickindole A, an anti-HCV oxazinoindole alkaloid from Penicillium raistrickii IMB17-034. J Nat Prod 82:1391-1395. https://doi.org/10.1021/acs.jnatprod.9b00259

Li J, Wang Y, Hao X, Li S, Jia J, Guan Y, Peng Z, Bi H, Xiao C, Cen S, Gan M (2019) Broad-spectrum antiviral natural products from the marine-derived Penicillium sp. IMB17-046. Molecules 24:2821-2831. https://doi.org/10.3390/molecules24152821

Li H, Liu SM, Yu XH, Tang SL, Tang CK (2020) Coronavirus disease 2019 (COVID 19): current status and future perspectives. Int J Antimicrob Agents 55:105951-105959. https://doi.org/10.1016/j. ijantimicag.2020.105951

Liao H-X, Sun D-W, Zheng C-J, Wang C-Y (2017) A new hexahydrobenzopyran derivative from the gorgonian-derived Fungus Eutypella sp. Nat Prod Res 31:1640-1646. https://doi. org/10.1080/14786419.2017.1285301

Liu F-A, Lin X, Zhou X, Chen M, Huang X, Yang B, Tao H (2017) Xanthones and quinolones derivatives produced by the deepsea-derived fungus Penicillium sp. SCSIO Ind16F01. Molecules 22:1999-2005. https://doi.org/10.3390/molecules22121999

Liu H, Chen Z, Zhu G, Wang L, Du Y, Wang Y, Zhu W (2017) Phenolic polyketides from the marine alga-derived Streptomyces sp. OUCMDZ-3434. Tetrahedron 73:5451-5455. https://doi.org/10.1016/j. tet.2017.07.052

Lou Z, Sun Y, Rao Z (2014) Current progress in antiviral strategies. Trends Pharmacol Sci 35:86-102. https://doi.org/10.1016/j. tips.2013.11.006

Ma X, Nong X-H, Ren Z, Wang J, Liang X, Wang L, Qi S-H (2017) Antiviral peptides from marine gorgonian-derived fungus Aspergillus sp. SCSIO 41501. Tetrahedron Lett 58:1151-1155. https://doi.org/10.1016/j.tetlet.2017.02.005

Manimaran M, Rajkumar T, Vimal S, Taju G, Majeed SA, Hameed AS, Kannabiran K (2018) Antiviral activity of 9 (10H)-Acridanone extracted from marine Streptomyces fradiae strain VITMK2 in Litopenaeus vannamei infected with white spot syndrome virus. Aquaculture 488:66-73. https://doi.org/10.1016/j. aquaculture.2018.01.032

Minagawa K, Kouzuki S, Yoshimoto J, Kawamura Y, Tani H, Iwata T, Terui Y, Nakai H, Yagi S, Hattori N, Fujiwara T, Kamigauchi $T$ (2002) Stachyflin and acetylstachyflin, novel anti-influenza A virus substances, produced by Stachybotrys sp. RF-7260. I. 
Isolation, structure elucidation and biological activities. J Antibiot 55:155-164. https://doi.org/10.1002/chin.200233246

Minagawa K, Kouzuki S, Kamigauchi T (2002) Stachyflin and acetylstachyflin, novel anti-influenza A virus substances, produced by Stachybotrys sp. RF-7260. II. Synthesis and preliminary structure-activity relationships of stachyflin derivatives. J Antibiot 55:165-171. https://doi.org/10.1002/chin.200233246

Miniyar PB, Murumkar PR, Patil PS, Barmade MA, Bothara KG (2013) Unequivocal role of pyrazine ring in medicinally important compounds: a review. Mini Rev Med Chem 13:1607-1625. https://doi.org/10.2174/1389557511313110007

Moghadamtousi SZ, Nikzad S, Kadir HA, Abubakar S, Zandi K (2015) Potential antiviral agents from marine fungi: an overview. Mar Drugs 13:4520-4538. https://doi.org/10.3390/md130 74520

Niu S, Si L, Liu D, Zhou A, Zhang Z, Shao Z, Wang S, Zhang L, Zhou D, Lin W (2016) Spiromastilactones: a new class of influenza virus inhibitors from deep-sea fungus. Eur J Med Chem 108:229_ 244. https://doi.org/10.1016/j.ejmech.2015.09.037

Niu S, Liu D, Shao Z, Proksch P, Lin W (2017) Eutypellazines A-M, thiodiketopiperazine-type alkaloids from deep sea derived fungus Eutypella sp. MCCC 3A00281. RSC Adv 7:33580-33590. https ://doi.org/10.1039/C7RA05774A

Numata A, Takahashi C, Matsushita T, Miyamoto T, Kawai K, Usami Y, Matsumura E, Inoue M, Ohishi H, Shingua T (1992) Fumiquinazolines, novel metabolites of a fungus isolated from a saltfish. Tetrahedron Lett 33:1621-1624. https://doi.org/10.1016/ S0040-4039(00)91690-3

Pang X, Lin X, Wang J, Liang R, Tian Y, Salendra L, Luo X, Zhou X, Yang B, Tu Z, Liu Y (2018) Three new highly oxygenated sterols and one new dihydroisocoumarin from the marine sponge-derived fungus Cladosporium sp. SCSIO41007. Steroids 129:41-46. https ://doi.org/10.1016/j.steroids.2017.12.001

Pech-Puch D, Berastegui-Cabrera J, Pérez-Povedano M, VillegasHernández H, Guillén-Hernández S, Cautain B, Reyes F, Pachón J, Gómez P, Rodríguez J, Jiménez C, Sánchez-Céspedes J (2020) Antiviral and antiproliferative potential of marine organisms from the Yucatan Peninsula. Front Mar Sci, Mexico. https://doi. org/10.3389/fmars.2020.00607

Qin C, Lin X, Lu X, Wan J, Zhou X, Liao S, Tu Z, Xu S, Liu Y (2014) Sesquiterpenoids and xanthones derivatives produced by sponge-derived fungus Stachybotry sp. HH1 ZSDS1F1-2. J Antibiot 68:121-125. https://doi.org/10.1038/ja.2014.97

Rowley DC, Kelly S, Kauffman CA, Jensen PR, Fenical W (2003) Halovirs A-E, new antiviral agents from a marine-Derived fungus of the genus Scytalidium. Bioorg Med Chem 11:4263-4274. https ://doi.org/10.1016/S0968-0896(03)00395-X

Saleem M, Nazir M, Ali MS, Hussain H, Lee YS, Riaz N, Jabbar A (2010) Antimicrobial natural products: an update on future antibiotic drug candidates. Nat Prod Rep 27:238-254. https://doi. org/10.1039/b916096e

Schobert R, Schlenk A (2008) Tetramic and tetronic acids: an update on new derivatives and biological aspects. Bioorg Med Chem 16:4203-4221. https://doi.org/10.1016/j.bmc.2008.02.069

Seghal Kiran G, Ramasamy P, Sekar S, Ramu M, Hassan S, Ninawe AS, Selvin J (2018) Synthetic biology approaches: towards sustainable exploitation of marine bioactive molecules. Int $\mathbf{J}$ Biol Macromol 112:1278-1288. https://doi.org/10.1016/j.ijbio mac.2018.01.149
Sun Y-L, Wang J, Wang Y-F, Zhang X-Y, Nong X-H, Chen M-Y, Xu X-Y, Qi S-H (2015) Cytotoxic and antiviral tetramic acid derivatives from the deep-sea-derived fungus Trichobotrys effuse DFFSCS021. Tetrahedron 71:9328-9332. https://doi.org/10.1002/ chin.201611226

Tian Y-Q, Lin X-P, Wang Z, Zhou X-F, Qin X-C, Kaliyaperumal K, Zhang T-Y, Tu Z-C, Liu Y (2015) Asteltoxins with antiviral activities from the marine sponge-derived fungus Aspergillus sp. SCSIO XWS02F40. Molecules 21:34-43. https://doi.org/10.3390/ molecules 21010034

Vijayaraj R, Altaff K, Rosita AS, Ramadevi S, Revathy J (2020) Bioactive compounds from marine resources against novel corona virus (2019-nCoV): in silico study for corona viral drug. Nat Prod Res. https://doi.org/10.1080/14786419.2020.1791115

Wang J-F, Liang R, Liao S-R, Yang B, Tu Z-C, Lin X-P, Wang B-G, Liu Y (2017) Vaccinols J-S, ten new salicyloid derivatives from the marine mangrove-derived endophytic fungus Pestalotiopsis vaccinii. Fitoterapia 120:164-170. https://doi.org/10.1016/j.fitot e.2017.06.013

Yang S-Q, Li X-M, Li X, Li H-L, Meng L-H, Wang B-G (2018) New citrinin analogues produced by coculture of the marine algalderived endophytic fungal strains Aspergillus sydowii EN-534 and Penicillium citrinum EN-535. Phytochem Lett 25:191-195. https://doi.org/10.1016/j.phytol.2018.04.023

Yasuhara-Bell J, Lu Y (2010) Marine compounds and their antiviral activities. Antiviral Res 86:231-240. https://doi.org/10.1016/j. antiviral.2010.03.009

Yu G, Zhou G, Zhu M, Wang W, Zhu T, Gu Q, Li D (2015) Neosartoryadins $\mathrm{A}$ and $\mathrm{B}$, fumiquinazoline alkaloids from a mangrovederived fungus Neosartorya udagawae HDN13-313. Org Lett 18:244-247. https://doi.org/10.1021/acs.orglett.5b02964

Yu M-L, Guan F-F, Cao F, Jia Y-L, Wang C-Y (2017) A new antiviral pregnane from a gorgonian-derived Cladosporium sp. fungus. Nat Prod Res 32:1260-1266. https://doi.org/10.1080/14786 419.2017.1342086

Zhang P, Li Y, Jia C, Lang J, Niaz S-I, Li J, Yuan J, Yu J, Chen S, Liu L (2017) Antiviral and anti-inflammatory meroterpenoids: stachybonoids A-F from the crinoid-derived fungus Stachybotrys chartarum 952. RSC Adv 7:49910-49916

Zhao X-Q (2011) Genome-based studies of marine microorganisms to maximize the diversity of natural products discovery for medical treatments. Evid Based Complement Alternat Med 2011:384572384584. https://doi.org/10.1007/978-1-4614-6418-1_759-1

Zhao Y, Si L, Liu D, Proksch P, Zhou D, Lin W (2015) Truncateols A-N, new isoprenylated cyclohexanols from the spongeassociated fungus Truncatella angustata with anti-H1N1 virus activities. Tetrahedron 71:2708-2718. https://doi.org/10.1016/j. tet.2015.03.033

Zhao Y, Liu D, Proksch P, Zhou D, Lin W (2018) Truncateols O-V, further isoprenylated cyclohexanols from the sponge-associated fungus Truncatella angustata with antiviral activities. Phytochemistry 155:61-68. https://doi.org/10.1016/j.phytochem.2018.07.017

Publisher's Note Springer Nature remains neutral with regard to jurisdictional claims in published maps and institutional affiliations. 